\title{
歴代の委員長を想 ら
}

一器械学会 30 周年に際して—

本学会前書記長 高 橋 勝 一 郎

日本医科器㖑学会が大正12年発足して以来こつに30年の齡を重ねて, 記念祝典を挙げられることは諴に扣目

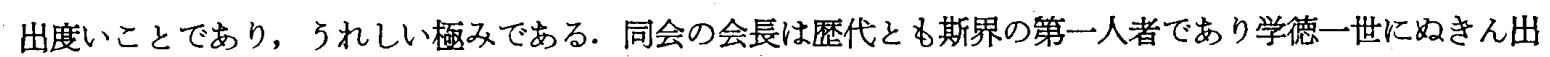
た方々であつたことは，誰もが諗めるところであつて，今さら㖼々を要しないのである. しかも，その女房 役である委員長の方々も，それぞれ人徳高く円满無げでよく会長をたすけ役員を引きいて，ひたすらに会運 隆昌に努力され，今日を築かれた次第で，その苦心と熱意とには深く感銘し，いろいろと思い出されるので ある以下楚代委員長に就いて感じたことの一，二を述へて学会育成に対しての御努力を偲びたいと思ら。

\section{初代委員長}

\section{故松本福松氏}

$\diamond$ 一初代委員長は故松本福松氏 (い卫しや松本器械店 先代）である.日本医科器械学会創立の主役者として この椅子につかねばならなかつたことは，十分らなず けるのである.故人の学会に対する熱意は，母が子に 対するような慈愛にあふれたもので，わきで見ていて よく拉心持がわかるのであつた. 余り熱心であるため に他から「あの会は松本さんの私物だ」などと言葉が るれるのも耳にした位いである.

○一あの大正期によくも学会の創設を著意され, 同志 を説いてその創立を決行され，営利を伴わない学会の 運営に手を染められた事は，真にその達識に敬服する 外はないのである．松本さんは殆ど毎月講演会の開催 をつずけられ，一人でも多く聴者の参集を念願されて 璉々呼びかけに努められたことも，なかなか真似ので きないことである．殊に講演会の席上，図表などの貼 付に委員長自ら諾々として当られた姿には眼頭さえあ つくなる思いであつた。

$\diamond$ 一当時経費も少く係員も常置できない状態で，やむ を得ない次第であつたと思われるのであるが，溢れる 愛会心がなければ容易には出来ない御努力と思い，唯 々感謝し，思い出をふかくするのである.

\section{二代目委員長}

\section{松永倉吉氏}

$\diamond$ 一次代は松永倉吉氏（現松永商店社長）が引ききうけ られたのであるが，松永氏る創立者の一人であり，否 応なしに就任を余儀なくさせられたわけで，会を愛す る念には誰にるヒヶをとら妨である。ある年の医科
器械展示会開催に際して, 場所の都合でその引渡しが 遅れ，開会までに時間が切迫しているとき，松永委員 長は洋服の上衣を妨で，机の運搬につとめられる姿 があつた。

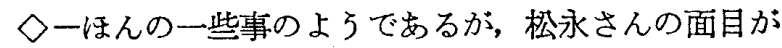
躍如として現われ，その会を思われる拉気持か脉々と して，にじみ出ているのである．松永さんが委員長を 引きうけられた時代は終戦などの混とん期で，何かと 仕事の遂行に不自由であり，上くもまあ，やりとげら れたものと感歓するのである.

\section{三代目委員長 \\ 市河作之助氏}

$\diamond$ 三代目の現委員長は市河作之助氏（市河思誠堂社 “長)であつて，日夜会務の総覧，会誌の糄集にと努力 をつずけて扮られ，日本医科器械学会隆盛をるたらさ れた事はこっく申し述べる必要むないのである。あ る年の会誌の編集のとき，市河さんは発熱して床につ いて居られたのであるが，会誌印刷の期日も迫り原稿 の放置をゆるさないので，床の中で病を扰して原稿作 りをされる始末で一冊の会誌刊行の裹にも斯うした茂 難が秘められていたのであつた.

$\diamond$ 一日本医科器械学会が30年の星霜を積まれ, 今や青 年として大活動の舞台に上られたのであるが，歷代会 長および委員長，ほか役員諸氏の，なみなみならぬ努 力と会員各位の非常な協力があつて，始めて求め得た 成果であり，器械同人の一人として满腔の謝意を表す るとともに，歷代委員長各位の扮骨折に梁い感銘を覚 えるあのである.

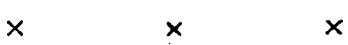

